\title{
Micrometeorological Measurements Reveal Large Nitrous Oxide Losses during Spring Thaw in Alberta
}

\author{
Thomas K. Flesch 1,*, Vern S. Baron ${ }^{2}$, John D. Wilson ${ }^{1}$, John A. Basarab ${ }^{3}$, \\ Raymond L. Desjardins ${ }^{4}$, Devon Worth ${ }^{4}$ and Reynald L. Lemke ${ }^{5}$ \\ 1 Department of Earth and Atmospheric Sciences, University of Alberta, Edmonton, AB T6G 2E3, Canada; \\ jaydee.uu@ualberta.ca \\ 2 Agriculture and Agri-Food Canada, Lacombe, AB T6G 2E3, Canada; vern.baron@agr.gc.ca \\ 3 Alberta Agriculture and Forestry, Lacombe, AB T6G 2E3, Canada; john.basarab@gov.ab.ca \\ 4 Agriculture and Agri-Food Canada, Ottawa, ON K1A 0C5, Canada; ray.desjardins@agr.gc.ca (R.L.D.); \\ devon.worth@agr.gc.ca (D.W.) \\ 5 Agriculture and Agri-Food Canada, Saskatoon, SK S7N 0X2, Canada; reynald.lemke@agr.gc.ca \\ * Correspondence: thomas.flesch@ualberta.ca; Tel.: +1-780-492-5406
}

Received: 10 February 2018; Accepted: 27 March 2018; Published: 29 March 2018

\begin{abstract}
Agricultural soils in Canada have been observed to emit a large pulse of nitrous oxide $\left(\mathrm{N}_{2} \mathrm{O}\right)$ gas during the spring thaw, representing a large percentage of the annual emissions. We report on three years of spring thaw $\mathrm{N}_{2} \mathrm{O}$ flux measurements taken at three Alberta agricultural sites: a crop production site (Crop), cattle winter-feeding site (WF), and a cattle winter-grazing site (WG). Soil fluxes were calculated with a micrometeorological technique based on the vertical gradient in $\mathrm{N}_{2} \mathrm{O}$ concentration above each site measured with an open-path (line-averaging) FTIR gas detector. The Crop and WG sites showed a clear $\mathrm{N}_{2} \mathrm{O}$ emission pulse lasting 10 to 25 days after thawing began. During this pulse there was a strong diurnal cycle in emissions that paralleled the cycle in near-surface soil temperature. The emission pulse was less pronounced at the WF site. The average spring thaw losses (over 25 to 31 days) were 5.3 (Crop), 7.0 (WF), and 8.0 (WG) kg N $\mathrm{N}_{2} \mathrm{~N}$ ha $^{-1}$, representing 1 to $3.5 \%$ of the annual nitrogen input to the sites. These large losses are higher than found in most previous western Canadian studies, and generally higher than the annual losses estimated from the Intergovernmental Panel on Climate Change and Canadian National Inventory Report calculations. The high $\mathrm{N}_{2} \mathrm{O}$ losses may be explained by high soil nitrate levels which promoted rapid denitrification during thawing. The application of a high resolution (temporal) micrometeorological technique was critical to revealing these losses.
\end{abstract}

Keywords: nitrous oxide; spring thaw; FTIR; flux chambers; inverse dispersion; flux-gradient

\section{Introduction}

Agricultural soils are the primary anthropogenic source of nitrous oxide $\left(\mathrm{N}_{2} \mathrm{O}\right)$ to the atmosphere [1], and quantifying $\mathrm{N}_{2} \mathrm{O}$ emission rates is important for greenhouse gas (GHG) inventory assessments and for developing GHG mitigation strategies. In temperate regions the spring thaw is well-known as a high $\mathrm{N}_{2} \mathrm{O}$ emission period [2-4] during which a large percentage of the annual $\mathrm{N}_{2} \mathrm{O}$ losses can occur [5,6]. Wagner-Riddle et al. [7] estimated that neglecting emissions during thawing leads to an underestimation of global agricultural $\mathrm{N}_{2} \mathrm{O}$ emissions by 17 to $28 \%$. An accurate accounting of emissions during the spring thaw is thus important to understanding agricultural GHG emissions.

The focus of this paper is $\mathrm{N}_{2} \mathrm{O}$ emitted during spring thaw from agricultural landscapes in the western Canadian province of Alberta. Previous studies from the region have reported a wide range of spring thaw emission losses. At cropping sites in central Alberta, Nyborg et al. [8] found 
exceptionally large spring losses $\left(16.3 \mathrm{~kg} \mathrm{~N}_{2} \mathrm{O}-\mathrm{N} \mathrm{ha}^{-1}\right)$, but at a nearby location Lemke et al. [6,9] and Izaurralde et al. [10] found much smaller losses $\left(0.04\right.$ to $\left.1.81 \mathrm{~kg} \mathrm{~N}_{2} \mathrm{O}-\mathrm{N} \mathrm{ha}^{-1}\right)$. Corre et al. [11], Pennock and Corre [12], and Pennock et al. [13] found small losses from sites in the neighboring province of Saskatchewan ( 0.047 to $\left.0.53 \mathrm{~kg} \mathrm{~N}_{2} \mathrm{O}-\mathrm{N} \mathrm{ha}^{-1}\right)$. The current regional perspective is that spring $\mathrm{N}_{2} \mathrm{O}$ emissions in western Canada are smaller than in eastern Canada [9], which contributes to low annual $\mathrm{N}_{2} \mathrm{O}$ emissions from western Canada [14].

Understanding spring $\mathrm{N}_{2} \mathrm{O}$ emissions is hindered by the difficult measurement environment. Non-steady state (NSS) chambers are the most commonly used measurement technique, but they are exceedingly difficult to use during the spring transition from snow and ice-covered soils, to an inhomogeneous mix of mud and puddles, to a more uniform dry surface. The small footprint of chambers also requires many replicates to adequately quantify an agricultural field [15]. The NSS chambers are also poorly suited for continuous measurements, whereas continuity of sampling is desirable in dynamic thawing environments [16]. Micrometeorological techniques avoid some of these logistical problems. Relying on gas concentration and wind measured in the free air above the surface, these techniques have large measurement footprints and are well suited to continuous measurements. While a handful of micrometeorological studies have measured spring thaw emissions in Canada (e.g., [17-20]), the complexity of the equipment and the analysis methods (compared to NSS chambers) have limited such measurements in western Canada.

This paper describes $\mathrm{N}_{2} \mathrm{O}$ fluxes measured during spring thaw using a rather new micrometeorological application. Measurements were made from three agricultural settings encountered in central Alberta: a cereal cropping site, a cattle winter-feeding site, and a cattle winter-grazing site. The last two sites correspond to the winter management of cattle in Alberta, where beef production is a major farming enterprise. The objective of this paper is to highlight the surprisingly large spring $\mathrm{N}_{2} \mathrm{O}-\mathrm{N}$ losses measured from the three study sites, to compare those losses to estimates made using the Intergovernmental Panel on Climate Change (IPCC, [21]) emission factor methodology used in the Canadian National Inventory Report (NIR, [14]), and to examine reasons for the large losses.

\section{Materials and Methods}

\subsection{Measurement Sites}

Measurements took place at the Lacombe Research Centre in central Alberta (lat. $52^{\circ} 28^{\prime} 06^{\prime \prime} \mathrm{N}$, long. $113^{\circ} 44^{\prime} 13^{\prime \prime} \mathrm{W}$, elev. $870 \mathrm{~m}$ ). The region is sub-humid with an average annual precipitation of $450 \mathrm{~mm}$ and snowfall near $1000 \mathrm{~mm}$. Soils at this location typically freeze in November and thaw in late March or early April. Transient thawing events may occur during the winter, but these were not studied here. Study locations were on black Chernozem clay loam having a soil organic $\mathrm{C}$ (SOC) content of $6 \%$ (0-15 cm depth). Soil $\mathrm{N}_{2} \mathrm{O}$ fluxes were measured from cropping (Crop), winter-feeding (WF), and winter-grazing (WG) sites. These sites were located within $1 \mathrm{~km}$ of each other (Figure 1) and had similar landform positions. Table 1 describes the site characteristics for the study period, and further management details can be found in Baron et al. [22] and Alemu et al. [23].

The Crop site was a 3 ha field where the cereal triticale $(\times$ triticosecale Wittmack) was grown for silage. The field was in pasture two years prior to our measurements. In 2013, the pasture vegetation was chemically burnt off (glyphosate), and the field was tilled for weed control and left fallow for the year. Triticale was sown in the spring of 2014 and harvested in the autumn. Soil $\mathrm{N}_{2} \mathrm{O}$ fluxes were measured in the spring of 2015.

The WF and WG sites represent contrasting choices for managing cattle herds in the western Canadian winter. In WF, the feed is trucked to the herd (e.g., concentrated in corrals). In WG, the herd graze a crop left on the field over the winter. Winter-grazing has been promoted as a GHG mitigation strategy, mainly due to the reduced fuel consumption compared with WF. The WF site was a 2.6 ha paddock holding about 50 animals over the winter (November-March). Feed was trucked in daily and 
put in feed bunks. The bunk locations were moved regularly within the paddock. Except for a bedding pack located away from our measurements, the site was an uneven grass surface with manure, some straw and some feed spillage. This area was not cropped or allowed to produce enough biomass to add substantial residue to the soil. The WG paddocks were approximately 2.5 ha in size, where corn (Zea mays L.) or triticale ( $\times$ triticosecale Wittmack) was grown over the summer, swathed in the autumn, and left for cattle to graze during the winter. The WG sites were tilled and fertilized in the spring prior to seeding. The location of the WG study paddock varied slightly each year, but it was always located beside other WG paddocks with similar management. Cattle were moved out of the WF and WG paddocks in the spring, and our soil flux measurements included periods with and without cattle in the paddocks. Cattle impacted the measurements only when animals blocked the concentration sensor paths for prolonged periods.

In terms of nitrogen and carbon substrates, the sites differed in terms of amount, sources (e.g., manure or fertilizer), and location (at surface or at depth). During spring they also differed in terms of soil moisture. In winter the tilled WG sites were covered by a sheet of ice and compacted snow created by cattle treading. As the spring thaw progressed there was sufficient water in the surface sheet to saturate the zone between the lower frozen layer and the surface. In contrast, the WF surface was more variable in terms of soil moisture. Because the animals treaded on unbroken grass and spent more time on straw bedding packs, there was less tracking and compaction and the WF site did not develop an ice-snow sheet. The Crop site had very little ice or standing water during the measurements, presumably due to the lack of animal treading.

The IPCC [21] uses a framework for estimating annual $\mathrm{N}_{2} \mathrm{O}$ losses from agricultural soils based on the amount of input $\mathrm{N}$ from different sources and the emission factors (EF) associated with each source. We calculate an "IPCC estimate" for our sites based on the various N inputs (Table 1) and the EF's recommended by IPCC (Tier I). The Canadian National Inventory report (NIR, [14]) uses the IPCC methodology with EF's developed for Canadian conditions (i.e., Tier II estimates), and we also calculate an "NIR estimate" of annual $\mathrm{N}_{2} \mathrm{O}$ emissions at our sites.

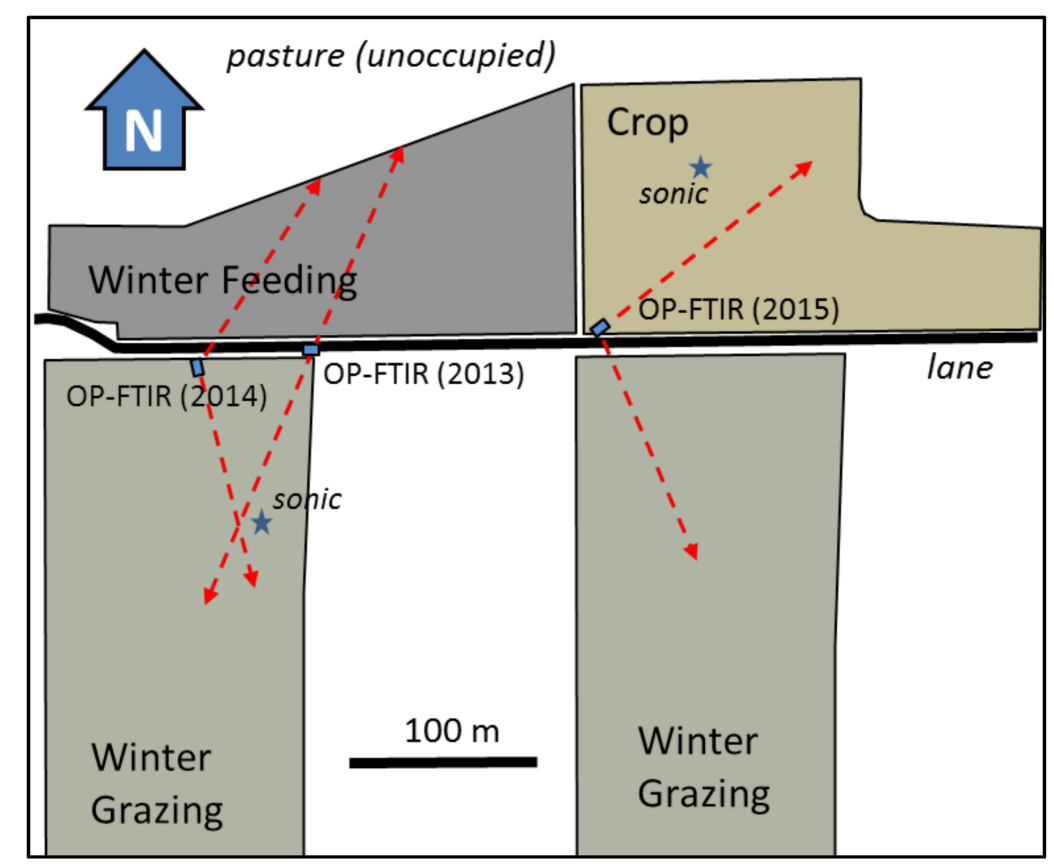

Figure 1. Map of the study site showing the positions of the open-path Fourier transform infrared (OP-FTIR) sensor, the concentration $\left(C_{\mathrm{L}}\right)$ measurement paths (dashed lines), and the sonic anemometers (sonic). 
Table 1. Details of the winter-feeding, winter-grazing and crop sites.

\begin{tabular}{|c|c|c|c|c|c|c|}
\hline & \multicolumn{2}{|c|}{$2012-2013$} & \multicolumn{2}{|c|}{$2013-2014$} & \multicolumn{2}{|c|}{ 2014-2015 } \\
\hline & Winter-Feeding & Winter-Grazing & Winter-Feeding & Winter-Grazing & Crop & Winter-Grazing \\
\hline Area of site (ha) & 2.6 & 2.5 & 2.6 & 2.5 & 2.5 & 2.5 \\
\hline Crop & - & corn & - & triticale & triticale & triticale \\
\hline Cattle-days ${ }^{\mathrm{a}}\left(\mathrm{ha}^{-1}\right)$ & 1346 & 1446 & 2894 & 459 & 0 & 1063 \\
\hline Cattle feed & barley-silage, straw & swathed corn & barley-silage, straw & swathed triticale & - & swathed triticale \\
\hline \multicolumn{7}{|l|}{$\mathrm{N}$ Inputs $\left(\mathrm{kg} \mathrm{ha}^{-1}\right)$ : } \\
\hline fertilizer ${ }^{b}$ & - & 55 & - & 92 & 55 & 55 \\
\hline manure ${ }^{c}$ & 217 & 181 & 593 & 72 & - & 117 \\
\hline roots + residue ${ }^{\mathrm{d}}$ & - & 82 & - & 172 & 56 & 118 \\
\hline mineralization $^{\mathrm{e}}$ & - & - & - & - & 60 & - \\
\hline $\mathrm{NH}_{3}$ deposition ${ }^{\mathrm{f}}$ & 5 & 5 & 5 & 5 & 5 & 5 \\
\hline Total & 222 & 323 & 598 & 341 & 176 & 295 \\
\hline \multicolumn{7}{|l|}{ Soil test $\mathrm{g}\left(\mu \mathrm{g} \mathrm{g}^{-1}\right)$} \\
\hline $\mathrm{NO}_{3}-\mathrm{N}$ & NA & 35 & NA & 58 & 57 & 28 \\
\hline $\mathrm{NH}_{4}-\mathrm{N}$ & NA & 5.4 & NA & 5.4 & 7.0 & 7.1 \\
\hline & \multicolumn{2}{|c|}{ 2012-2013 } & \multicolumn{2}{|c|}{ 2013-2014 } & \multicolumn{2}{|c|}{ 2014-2015 } \\
\hline Precipitation (Sep.-Apr.) & \multirow{2}{*}{\multicolumn{2}{|c|}{$\begin{array}{c}133 \mathrm{~mm} \\
11 \mathrm{Nov} / 1 \mathrm{Apr}\end{array}$}} & \multicolumn{2}{|c|}{$173 \mathrm{~mm}$} & \multirow{2}{*}{\multicolumn{2}{|c|}{$162 \mathrm{~mm}$}} \\
\hline Soil freeze/thaw: $5 \mathrm{~cm}$ & & & \multirow{2}{*}{\multicolumn{2}{|c|}{$\begin{array}{c}7 \text { Dec. /9 Apr. } \\
317\end{array}$}} & \multirow{2}{*}{\multicolumn{2}{|c|}{$\begin{array}{c}14 \text { Nov./18 Mar. } \\
339\end{array}$}} \\
\hline CFD ${ }^{h}$ & \multicolumn{2}{|c|}{$\begin{array}{l}11 \text { Nov./ 1 Apr. } \\
432\end{array}$} & & & & \\
\hline
\end{tabular}

${ }^{a}$ Cattle moved onto the sites in November and removed between late February and April; ${ }^{\mathrm{b}}$ Fertilizer applied the previous spring according to soil test recommendations; ${ }^{\mathrm{c}}$ Calculated from average $\mathrm{N}$ excretion per cow [24]; ${ }^{\mathrm{d}}$ Crop residue determined according to Baron et al. [22]; root mass estimated from above-ground biomass using the ratio method of Janzen et al. [25]; $\mathrm{N}$ from Dumas combustion method [26]; ${ }^{\mathrm{e}}$ Estimated $\mathrm{N}$ gain due to change from pasture to cropland (2 years prior), as outlined in Canada's National Inventory Report [14] for a land use change to "increased annuals" for the Parklands region; ${ }^{\mathrm{f}}$ Atmospheric deposition estimate from Janzen et al. [25]; ${ }^{\mathrm{g}}$ Nutrients in $0-15 \mathrm{~cm}$ layer, autumn measurements; ${ }^{\mathrm{h}}$ Cumulative freezing days [7]. 


\subsection{Flux Measurements}

A micrometeorological method was used to calculate soil $\mathrm{N}_{2} \mathrm{O}$ fluxes based on the vertical gradient in $\mathrm{N}_{2} \mathrm{O}$ measured above the field sites. A long-line averaging open-path sensor was used to measure gas concentrations, and details of the flux calculation are given in Flesch et al. [27]. Only an overview of the measurements is given here.

The University of Wollongong open-path Fourier transform infrared (OP-FTIR) system [28] measures path-average $\mathrm{N}_{2} \mathrm{O}$ concentration $\left(C_{\mathrm{L}}\right)$ by collecting and analysing the spectrum of light, created from an infra-red source, which has traversed an atmospheric path. The FTIR spectrometer (Matrix-M IR cube, Bruker Optik, Ettlingen, Germany) sends an infrared beam to a distant retroreflector which is returned along the same path to the detector. In this study the 1-way path lengths ranged from 120 to $140 \mathrm{~m}$. The spectrometer and detector were mounted on a motorised pan-tilt head (Figure 2) to allow the unit to be aimed at different retroreflectors. Fluxes of $\mathrm{N}_{2} \mathrm{O}$ were calculated from the difference in $C_{\mathrm{L}}$ in two vertically offset paths. Some measurements used a "slant path" configuration where the OP-FTIR was aimed directly at "high" and "low" reflectors, and some used a periscope configuration where the lower path was directed closer to ground (to increase the vertical path separation and increase measurement sensitivity).
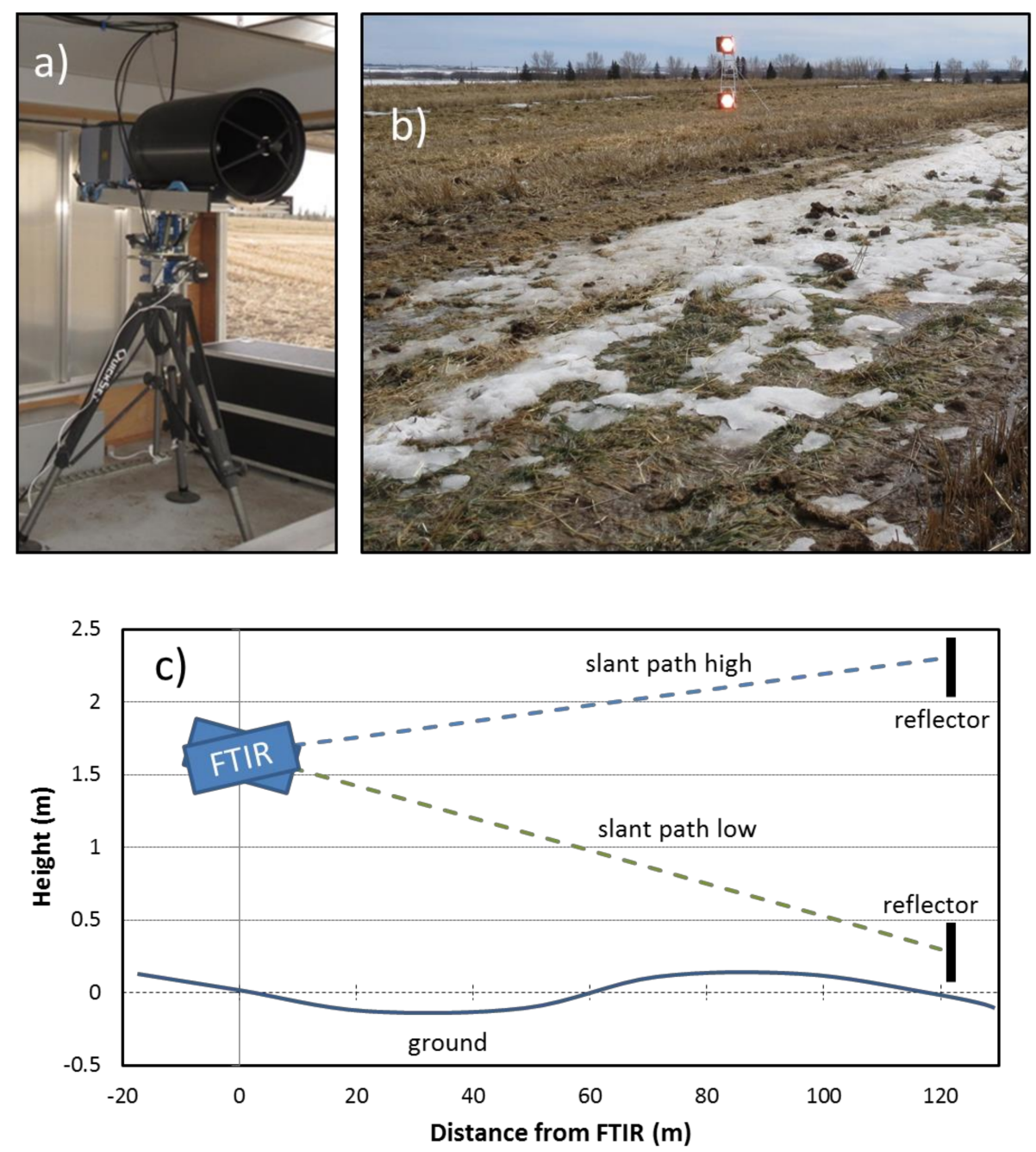

Figure 2. The OP-FTIR system: (a) sensor and aiming motors (in trailer); (b) winter-grazing (WG) field site showing high and low OP-FTIR reflectors; (c) idealized drawing of the system; The WG site in (b) was photographed on a day having near-maximum $\mathrm{N}_{2} \mathrm{O}$ emissions. 
In each of three study years the OP-FTIR (located in a trailer) was positioned to measure emissions concurrently from two adjacent sites. Retroreflector pairs (high and low) were placed within or beside the two sites. The OP-FTIR was sequentially aimed at the four reflectors during a 10-min cycle: $4 \times 2$-min measurement, plus $4 \times 30$-s aiming time. A 30-min average $C_{\mathrm{L}}$ for each path was calculated from three measurement cycles.

The freely available software "WindTrax" was used to calculate $\mathrm{N}_{2} \mathrm{O}$ fluxes based on $C_{\mathrm{L}}$, wind measurements, and a map of paddock boundaries and detector paths. In this "inverse dispersion" method, the flux is calculated by computationally matching a concentration field provided by the WindTrax dispersion model to the measured $C_{\mathrm{L}}$ pair (high and low). This is equivalent to a classic flux-gradient micrometeorological calculation, but modified to account for the limited (non-infinite) fetch conditions [29]. We assume there is no surface $\mathrm{N}_{2} \mathrm{O}$ flux outside the mapped field boundaries.

A 3-D sonic anemometer (CSAT-3, Campbell Sci., Logan, UT, USA) located within or adjacent to the sites provided the wind measurements needed for the flux calculations (friction velocity $u^{*}$, Obukhov stability length $L$, the inferred surface roughness length $z_{0}$, wind direction $\beta$, and velocity standard deviations $\sigma_{\mathrm{u}, \mathrm{v}, \mathrm{w}}$ ) as detailed in Flesch et al. [30]. WindTrax inputs $C_{\mathrm{L}}$ pairs and the wind information, and outputs the $\mathrm{N}_{2} \mathrm{O}$ flux and a background $\mathrm{N}_{2} \mathrm{O}$ concentration (which is not used here).

In WindTrax, the $C_{\mathrm{L}}$ paths are represented as straight lines over a flat ground surface by specifying a beginning and ending path height. These lines were calculated by a linear fit of path heights measured every $20 \mathrm{~m}$ along the length of each path. Flux uncertainty (expressed as a standard deviation, $1-\sigma$ ) was estimated using an error propagation analysis based on the precision of the $C_{\mathrm{L}}$ measurements $\left(0.3 \mathrm{ppb}_{\mathrm{v}}\right)$ and uncertainty in the dispersion model calculations [27]. A threshold $u^{*}$ was used to remove low wind periods when the dispersion model calculations are likely to be inaccurate. To retain as many measurement periods as possible we use a $u^{*}$ threshold of $0.05 \mathrm{~m} \mathrm{~s}^{-1}$; a value lower than used in many inverse-dispersion studies. We expect this choice to result in some erroneous flux outliers, but not to markedly alter the accuracy of the full dataset [31]. We also justify the inclusion of low $u^{*}$ data because we calculate an uncertainty for each observation, explicitly recognizing that low $u^{*}$ periods are associated with high uncertainty.

Soil temperature at a $5 \mathrm{~cm}$ depth $\left(T_{\text {soil }}\right)$ was measured at a weather station (under grass) approximately $1000 \mathrm{~m}$ from the field sites. The relationship between $T_{\text {soil }}$ and the soil temperatures at our sites is thus only approximate. Measuring actual site temperatures would be difficult given the presence of cattle and the large spatial inhomogeneity of surface conditions during thawing.

The $\mathrm{N}_{2} \mathrm{O}$ flux measurements were not fully continuous. Good observations range from $39 \%$ to $59 \%$ of the overall deployment period. Data gaps occurred when the OP-FTIR signals were low (e.g., misalignment, snow, blocking cattle), when $u^{*}$ was below the measurement threshold (e.g., low winds), or when the equipment was turned off (e.g., a windstorm). To better represent daily average emissions, we "gap-filled" the missing flux observations. A good correlation was observed between $\mathrm{N}_{2} \mathrm{O}$ flux and $T_{\text {soil }}$ during periods when emissions were large, and this relationship was the basis of our gap filling. Best-fit linear relationships between flux and $T_{\text {soil }}$ was calculated for each day using the good flux observations for that day (and \pm 1 day), and missing fluxes were estimated using $T_{\text {soil }}$ at those times.

\section{Results}

\subsection{Spring Fluxes}

Figure 3 shows the time series of $\mathrm{N}_{2} \mathrm{O}$ fluxes at one of our sites (Crop). Each of the 670 observations (circles) in the figure represents a 30-min average flux to/from the surface. Positive values are emissions to the atmosphere, negatives are deposition to the soil. The figure illustrates several interesting features. First, a spring rise in $\mathrm{N}_{2} \mathrm{O}$ emissions coincides with $T_{\text {soil }}(5 \mathrm{~cm})$ rising above $0{ }^{\circ} \mathrm{C}$. Second, immediately after thawing there was a strong diurnal cycle in the flux that followed the cycle in $T_{\text {soil }}$. The correlation between the flux and $T_{\text {soil }}$ reached as high as $r=0.84$ during high emission days. This meant that 
maximum emissions tended to occur in the evening near the time of maximum $T_{\text {soil }}$ (approx. 21:00 local time) with minimums in the late morning near the time of minimum $T_{\text {soil }}$ (approx. 11:00). A diurnal cycle in $\mathrm{N}_{2} \mathrm{O}$ emissions has been seen in many other studies (e.g., [32]). We also observed periods of negative $\mathrm{N}_{2} \mathrm{O}$ fluxes (soil consumption). Generally, the negative fluxes were not measurably different from zero (e.g., the measurement uncertainty $1-\sigma$ spans zero). The exception was the Crop site in 2015 where, several days after thawing, we observed a pattern of measurable consumption during the daytime.

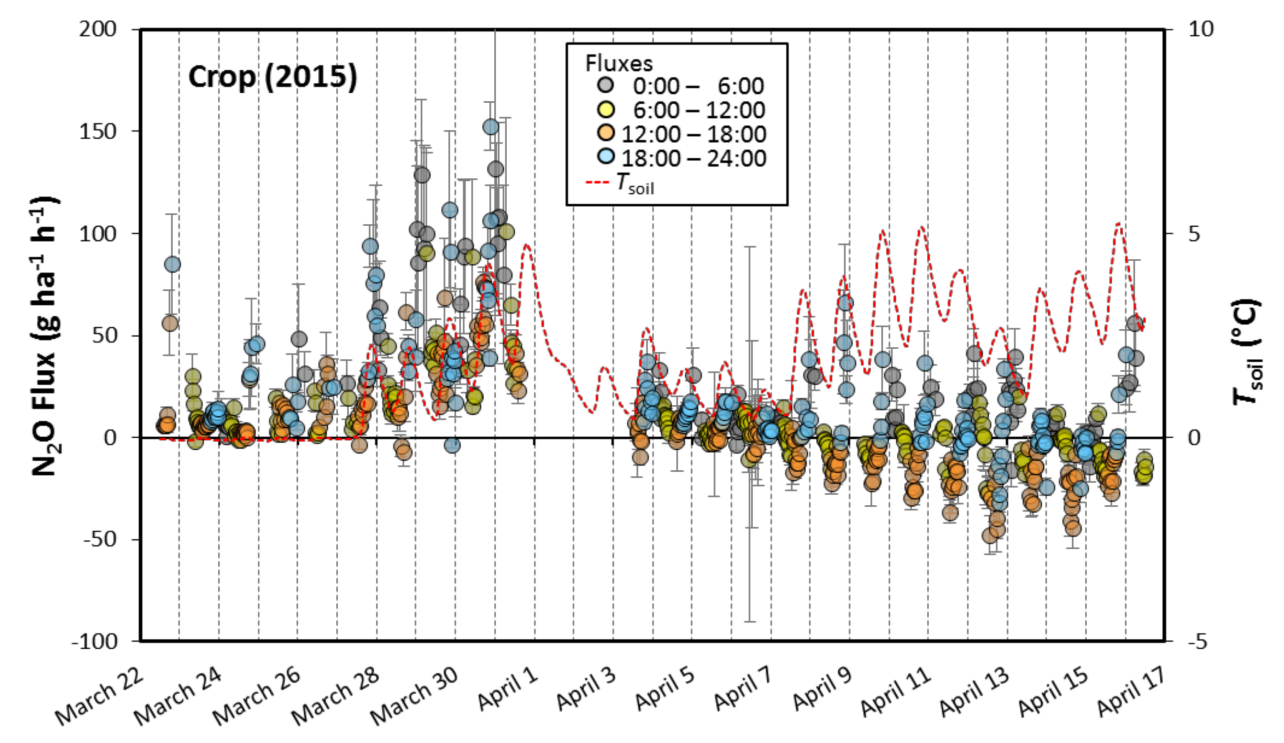

Figure 3. Time series of $\mathrm{N}_{2} \mathrm{O}$ fluxes from the Crop site (circles), and soil temperature at $5 \mathrm{~cm}$ depth $\left(T_{\text {soil }}\right)$ taken at a weather station near the site (red dashed line). Error bars correspond to a $1-\sigma$ calculation of flux uncertainty. Symbol color indicates the time of day of the flux observation. Vertical gridlines show midnight at each date.

\subsection{Daily Emissions}

Figure 4 displays daily $\mathrm{N}_{2} \mathrm{O}$ fluxes plotted against the number of days after $T_{\text {soil }}$ first exceeded $0{ }^{\circ} \mathrm{C}$ during the thaw. The emission pulse at the Crop site is the most distinct and intense of our three sites. Because the flux measurements in this case began after a brief (two-day) thaw, we may have missed the beginning of the pulse. However, after that weak thaw the soil re-froze and our measurements began. During the re-freeze we observed moderate levels of emissions, but after re-thawing the emissions rose dramatically to nearly $2 \mathrm{~kg} \mathrm{~N}_{2} \mathrm{O} \mathrm{ha}^{-1} \mathrm{~d}^{-1}$. This was the highest daily losses we observed. After two days of very high emissions, there was a rapid decline to near-zero values within a week, and thereafter there were several days of soil consumption.

At the WG sites $(2013,2014,2015)$ the fluxes were low prior to thawing. After $T_{\text {soil }}$ exceeded $0{ }^{\circ} \mathrm{C}$ there was a dramatic rise in emissions, with maximum daily losses occurring between 6 and 18 days after thawing began. The maximum emission rates were similar over the three years of WG observations, between 1 and $1.5 \mathrm{~kg} \mathrm{~N}_{2} \mathrm{O} \mathrm{ha}^{-1} \mathrm{~d}^{-1}$. The duration of the emission pulse in 2013 was longer than in 2014 and 2015, which we attribute to cooler post-thaw conditions. The 2015 pulse was delayed compared to 2013 and 2014, likely due to refreezing of the soil after weak thawing.

The emission pattern at the WF site is different from that of the Crop and WG sites. At the WF site, we observed moderate emissions of $\mathrm{N}_{2} \mathrm{O}$ prior to thawing (when air temperature was also well-below $0{ }^{\circ} \mathrm{C}$ ). Perhaps this is due to the location of the $\mathrm{N}$ substrate. Manure deposited over the winter at the WF site was likely to reside on top of the grass surface, with denser areas of manure exposed above the melting snow. This may have resulted in a warmer microclimate within and under the manure than indicated by either soil or air temperature. Emissions at the WF site did rise after thawing, but not as 
dramatically as at the Crop and WG sites, and thereafter emissions reached an irregular plateau that lasted through the measurement period. Unlike the Crop and WG sites, it is likely that significant $\mathrm{N}_{2} \mathrm{O}$ losses occurred at the WF site before our measurements began (prior to thawing) and continued after the measurements concluded.

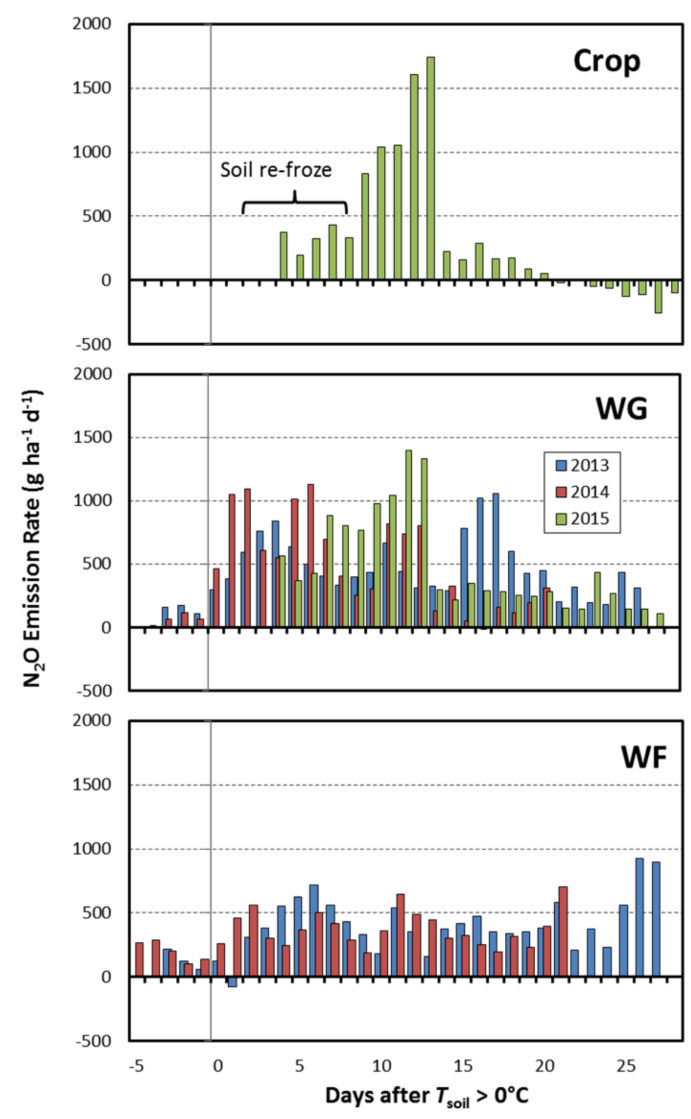

Figure 4. Daily $\mathrm{N}_{2} \mathrm{O}$ emission rates from the three sites during the spring thaw. Emissions plotted versus days after soil temperature at $5 \mathrm{~cm}$ depth $\left(T_{\text {soil }}\right)$ first exceeded $0{ }^{\circ} \mathrm{C}$.

\subsection{Spring $\mathrm{N}_{2} \mathrm{O}$ Losses}

Table 2 gives the accumulated $\mathrm{N}_{2} \mathrm{O}-\mathrm{N}$ losses (gap-filled) over the measurement periods (25 to 31 days). Losses range from 5.3 to $8.9 \mathrm{~kg} \mathrm{~N}_{2} \mathrm{O}-\mathrm{N} \mathrm{ha}{ }^{-1}$. For the WF and WG cattle sites, this represents 1 to $3.5 \%$ of the annual $\mathrm{N}$ input (fertilizer + residue + deposited manure $+\mathrm{NH}_{3}$ deposition), while for the Crop site, the loss represents $3 \%$ of the $\mathrm{N}$ input (Table 1 ). These are large losses considering the annual $\mathrm{N}_{2} \mathrm{O}-\mathrm{N}$ losses from agricultural soils are typically assumed to be 1 to $2 \%$ of the annual input $\mathrm{N}$ [21].

The IPCC and NIR estimates of $\mathrm{N}_{2} \mathrm{O}-\mathrm{N}$ loss are given in Table 2. For five of the six site-years, the IPCC estimates of annual $\mathrm{N}_{2} \mathrm{O}-\mathrm{N}$ losses are much smaller than our measured spring losses. Only at the WF site in 2014 did the annual IPCC estimate exceed the measured springtime loss; and because we believe emissions at the WF site occurred both before and after our measurements, this one exception may not be true. The difference between the IPCC-estimated and the measured losses was greatest at the Crop site, where the IPCC estimate was a third of the measured spring losses.

The NIR estimates of annual $\mathrm{N}_{2} \mathrm{O}-\mathrm{N}$ losses were lower than the corresponding IPCC values, which increased the discrepancies with our measurements. The difference between the NIR estimated and the measured losses is largest for the WF sites, where the NIR estimates are only 2 and $5 \%$ of the measured spring losses. This difference is due to the very low emission factor assumed by NIR for manure deposited on "pasture, range, and paddock" in western Canadian: $\mathrm{EF}_{\mathrm{PRP}}=0.00043$ (kg emitted 
$\mathrm{N}_{2} \mathrm{O}-\mathrm{N} / \mathrm{kg}$ manure-N). For the NIR estimates to agree with our WF measurements would require $\mathrm{EF}_{\mathrm{PRP}}>0.011$ (2013) or $>0.035$ (2014).

Table 2. Spring thaw $\mathrm{N}_{2} \mathrm{O}-\mathrm{N}$ emission losses.

\begin{tabular}{|c|c|c|c|c|c|c|}
\hline & \multirow{2}{*}{$\begin{array}{l}\text { Crop } \\
2015\end{array}$} & \multicolumn{2}{|c|}{ Winter-Feeding } & \multicolumn{3}{|c|}{ Winter-Grazing } \\
\hline & & 2013 & 2014 & 2013 & 2014 & 2015 \\
\hline $\begin{array}{l}\mathrm{N}_{2} \mathrm{O} \text { Measurements }\left(\mathrm{kg} \mathrm{N}_{2} \mathrm{O}-\mathrm{N} \mathrm{ha}^{-1}\right) \\
{ }_{2} \mathrm{O}-\mathrm{N} \text { loss (\# days) }\end{array}$ & $5.3(25)$ & $7.7(31)$ & $6.3(29)$ & $8.9(31)$ & $7.3(29)$ & $7.7(25)$ \\
\hline $\mathrm{N}_{2} \mathrm{O}-\mathrm{N}$ Loss Estimates & & & & & & \\
\hline IPCC: annual loss a & 1.8 & 4.4 & 11.9 & 5.0 & 4.1 & 4.1 \\
\hline NIR: annual loss $\mathrm{b}$ & 1.1 & 0.1 & 0.3 & 3.1 & 3.2 & 2.8 \\
\hline Freibauer: annual loss ${ }^{c}$ & 17.9 & & & 11.3 & 17.8 & 9.8 \\
\hline
\end{tabular}

a Intergovernmental Panel on Climate Change (IPCC) methodology [21] with Tier 1 emission factors, where atmospheric $\mathrm{NH}_{3}-\mathrm{N}$ deposition is added to the fertilizer $\mathrm{N}$. Indirect $\mathrm{N}_{2} \mathrm{O}$ emissions not included; ${ }^{b}$ NIR methodology [14] with precipitation/potential evapotranspiration (P/PE) for the ecological region (0.65). For the WF site the manure is considered as deposited on "pasture, range, and paddock"; for the WG site the manure is treated as organic fertilizer. Indirect $\mathrm{N}_{2} \mathrm{O}$ emissions not included; ${ }^{\mathrm{c}}$ Estimate using Freibauer [33] formula for arable soils in climate with severe winter frost (Europe). Fertilizer and manure used as $\mathrm{N}$ inputs. Assume soil-test $\mathrm{N}\left(\mathrm{NO}_{3}\right.$ $+\mathrm{NH}_{4}$ ) representative of " $\mathrm{A}$ " horizon.

\section{Discussion}

A large spring emission pulse of $\mathrm{N}_{2} \mathrm{O}$ was observed at the Crop and WG sites. The beginning of the pulse was associated with near-surface soil temperatures rising above $0{ }^{\circ} \mathrm{C}$, and the pulse lasted for 10 to 25 days. During the pulse, there was a strong diurnal cycle in emissions paralleling the cycle in near-surface soil temperature. The emission pulse was less distinctive at the WF site, where emissions occurred prior to thawing, and after thawing the emissions rose to a long-lasting plateau (that likely continued after measurements ended).

Total spring thaw $\mathrm{N}_{2} \mathrm{O}$ losses were consistently higher than expected at the three sites. When compared to other thaw measurements from western Canada, only those of Nyborg et al. [8] are of larger magnitude. The losses are also larger than the annual losses estimated using IPCC and NIR methodologies. In a global context, Shcherbak et al. [34] examined $\mathrm{N}_{2} \mathrm{O}$ losses from more than 850 studies, and our spring losses are larger than the annual losses in more than $90 \%$ of those studies. What explains these high losses?

\subsection{Soil $\mathrm{NO}^{-}{ }_{3}-\mathrm{N}$ Levels}

Soil $\mathrm{NO}^{-}{ }_{3}$ (nitrate) levels measured from our tilled Crop and WG sites were relatively high, with surface $\mathrm{NO}^{-}{ }_{3}-\mathrm{N}$ values greater than $25 \mathrm{\mu g} \mathrm{g}^{-1}$ (Table 1). Lemke et al. [6] and Izaurralde et al. [10] found a positive correlation between autumn nitrate levels and the magnitude of spring $\mathrm{N}_{2} \mathrm{O}$ emissions in western Canada. Thus, high nitrate levels may explain the high $\mathrm{N}_{2} \mathrm{O}$ losses at the Crop and WG sites as compared with other regional studies where nitrate levels were lower (e.g., [10]). The particularly large nitrate "pool" at the Crop site would be available for rapid denitrification given that SOC levels were unlikely to be limiting [35], which helps explain the shorter and more intense $\mathrm{N}_{2} \mathrm{O}$ emission peak at the Crop site.

The role of high soil nitrate levels in explaining the high $\mathrm{N}_{2} \mathrm{O}$ losses is also suggested by calculations made using the emissions model developed by Freibauer [33]. This empirical model-developed for arable soils in Europe having severe winter frost—calculates emissions based on soil N inputs (similar to the IPCC procedure) but adds a term based on the soil N levels. Applying Freibauers' model to our Crop and WG sites (Table 2) results in much larger annual $\mathrm{N}_{2} \mathrm{O}-\mathrm{N}$ loss estimates than those from the IPCC and NIR calculations. When we consider that our spring observations will only be a portion of the annual losses, Freibauers' larger estimates better align with our measurements. 


\subsection{Other Factors}

We previously speculated that high $\mathrm{N}_{2} \mathrm{O}-\mathrm{N}$ losses from our WG sites was due to animal treading that created compacted and waterlogged soil conditions during the thaw [27]. These conditions are known to be associated with high $\mathrm{N}_{2} \mathrm{O}$ losses [36]. But our observations seem to contradict that explanation, since $\mathrm{N}_{2} \mathrm{O}$ emissions were nearly as large from the Crop site as from the WG sites, which had similar crop and soil conditions except for the presence of animal treading.

Wagner-Riddle et al. [7] related the magnitude of freeze-thaw-induced $\mathrm{N}_{2} \mathrm{O}$ losses to the duration and intensity of the winter freeze, as quantified by the cumulative freezing days (CFD). They proposed that high $\mathrm{N}_{2} \mathrm{O}$ losses are correlated with a high CFD (i.e., long and/or intense winter). The CFD at our sites (Table 1) is not large in the context of the studies examined by Wagner-Riddle et al. [7], but our $\mathrm{N}_{2} \mathrm{O}$ losses are high relative to those studies, indicating that freeze intensity is unlikely to be an explanation for our high losses.

\subsection{Measurement Technique}

Could the high emission losses we measured relative to other studies simply reflect methodological differences? When we compare our results with other western Canadian studies we are usually comparing near-continuous micrometeorological measurements with once-a-day or less frequent NSS chamber measurements. Venterea [37] concluded that typical NSS chamber procedures underestimate $\mathrm{N}_{2} \mathrm{O}$ emissions by 20 to $50 \%$. The timing of once-a-day measurements can also bias the inferred emission losses [38,39]. In many chamber studies emissions are measured during mid-day, which was a time of relatively low emissions at our sites. Our data shows that a single flux measurement at noon would underestimate $\mathrm{N}_{2} \mathrm{O}-\mathrm{N}$ losses by $80 \%$ (Crop) and $40 \%$ (WF and WG) compared with the continuous record. If average losses are estimated from once-a-week measurements (at noon), the estimates would have a haphazard relationship to the actual losses. Depending on the day of the week sampled, the estimates might be reasonably accurate or might be wrong by a factor of 50 . It is thus possible that a combination of a chamber bias plus a time-of-day bias could explain large differences between our measurements and those of other studies.

\subsection{Soil Consumption}

At the Crop site we observed surprisingly large rates of soil consumption after the initial thawing emission pulse, with maximum 30-min consumption rates of approximately $50 \mathrm{~g} \mathrm{ha}^{-1} \mathrm{~h}^{-1}$. Chapuis-Lardy et al. [40] summarized several studies measuring $\mathrm{N}_{2} \mathrm{O}$ consumption, and our maximum rates are nearly 10 times larger than the largest rate in those summarized studies. Over $24 \mathrm{~h}$ our high rates of consumption were partially balanced by periods of emissions, although the daily average consumption rate was still large (approximately $100 \mathrm{~g} \mathrm{ha}^{-1} \mathrm{~d}^{-1}$ ). It is interesting that consumption occurred after the soil surface had dried, whereas it is often assumed that consumption is associated with wet conditions (i.e., the reduction of $\mathrm{N}_{2} \mathrm{O}$ to $\mathrm{N}_{2}$ by denitrifiers). However, the factors regulating $\mathrm{N}_{2} \mathrm{O}$ consumption are not well-understood, and consumption has been observed in dry soils [40].

Could the high $\mathrm{N}_{2} \mathrm{O}$ consumption rates we observed indicate a problem with the micrometeorological measurement technique? We cannot claim the technique is without error, but we note that consumption was seen (clearly) for only one of the six site-years, and that when consumption was observed at the Crop site in 2015, the adjacent winter-grazing site showed emissions. This provides evidence that consumption fluxes are not an artifact of the technique.

Surface $\mathrm{N}_{2} \mathrm{O}$ flux is the net of consumption and production processes. High net positive surface flux events may actually be the result of high consumption rates coupled with even higher production rates [41]. The high net negative surface flux events at our crop site may be the result of a temporary de-coupling of these two processes where production was inhibited but not consumption. Thus, it should not be surprising that at a site where we observed periods of very high emission rates, there might also be a potential for alternative periods of high soil consumption. 


\section{Conclusions}

Our three Alberta sites emitted large amounts of $\mathrm{N}_{2} \mathrm{O}$ during the spring thaw. Emission losses were consistently higher than expected given the results of previous studies in the region, and also higher than estimates of annual losses from IPCC and NIR emission factor models. We believe the high $\mathrm{N}_{2} \mathrm{O}$ losses are due to two factors. The ultimate cause is the high soil nitrate levels at our sites (at least for the Crop and WG sites). This large nitrate "pool" was available for rapid denitrification once thawing began. But because the fluxes had a strong diurnal cycle, with maximum emissions during the evening and minimums during the late-morning, the quantification of these losses was contingent on having high temporal resolution measurements. The application of a micrometeorological technique was thus critical to capturing the spring thaw emission pulse from our $\mathrm{N}$ rich soils. Techniques based on spot measurements (daily or less frequent) would likely have failed to document these events.

The OP-FTIR gradient system was particularly appropriate for examining the spring thaw environment. It has the usual advantages of micrometeorological techniques: it can (in principle) make continuous flux measurements with a measurement footprint much larger than chamber methods. And because of the long $C_{\mathrm{L}}$ measurement paths, the system has an even larger footprint than techniques based on point measurements. We estimate our measurement footprint was of order $10,000 \mathrm{~m}^{2}$. Figure 2 shows the WG site during a day with near-maximum $\mathrm{N}_{2} \mathrm{O}$ emissions, when the surface was a mix of snow, ice, standing water, and dry soil. The large footprint of the OP-FTIR system should more closely represent field-scale emissions at this site when compared with other approaches. Finally, the open-path sensor was a logistically practical option for the difficult spring thaw environment: we did not need to establish sensors in the field where melting might create water or mud holes, nor did we need to fence-off cattle to protect the expensive sensor.

Acknowledgments: A special thanks to Adele Ohama for helping to compile and analyze the agronomic data. This study would not have been possible without the assistance of Cletus Sehn and the beef crew at the Lacombe Research Station. Dave Young's help was greatly appreciated. The comments of two anonymous reviewers were very constructive. Funding and equipment was provided by the Canadian Agricultural Greenhouse Gases Program.

Author Contributions: T.K.F. carried out the studies, collected and post-processed data, and wrote the draft. V.S.B., J.D.W., and J.A.B. participated in designing experiments and collecting data. D.W. contributed to IPCC and NIR emission calculations. All authors participated in writing of the manuscript.

Conflicts of Interest: The authors declare no conflict of interest.

\section{References}

1. Syakila, A.; Kroeze, C. The global nitrous oxide budget revisited. Greenh. Gas Meas. Manang. 2011, 1, 17-26. [CrossRef]

2. Bremner, J.M.; Robbins, S.G.; Blackmer, A.M. Seasonal variability in emission of nitrous oxide from soil. Geophys. Res. Lett. 1980, 7, 641-644. [CrossRef]

3. Duxbury, J.M.; Bouldin, D.R.; Terry, R.E.; Tate III, R.L. Emissions of nitrous oxide from soils. Nature 1982, 298, 462-464. [CrossRef]

4. Christensen, S.; Tiedje, J.M. Brief and vigorous $\mathrm{N}_{2} \mathrm{O}$ production by soil at springthaw. J. Soil Sci. 1990, 41, 1-4. [CrossRef]

5. Wagner-Riddle, C.; Thurtell, G.W.; King, K.M.; Kidd, G.K.; Beauchamp, E.G. Nitrous oxide and carbon dioxide fluxes from a bare soil using a micrometeorological approach. J. Environ. Qual. 1997, 25, 898-907. [CrossRef]

6. Lemke, R.L.; Izaurralde, R.C.; Nyborg, M. Seasonal distribution of nitrous oxide emissions from soil in the Parkland region. Soil Sci. Soc. Am. J. 1998, 62, 1320-1326. [CrossRef]

7. Wagner-Riddle, C.; Congreves, K.A.; Abalos, D.; Berg, A.A.; Brown, S.E.; Ambadan, J.T.; Gao, X.; Tenuta, M. Globally important nitrous oxide emissions from croplands induced by freeze-thaw cycles. Nat. Geosci. 2017, 10, 279-283. [CrossRef]

8. Nyborg, M.; Laidlaw, J.W.; Solberg, E.D.; Malhi, S.S. Denitrification and nitrous oxide emissions from a Black Chernozemic soil during spring thaw in Alberta. Can. J. Soil Sci. 1997, 77, 153-160. [CrossRef] 
9. Lemke, R.L.; Izaurralde, R.C.; Nyborg, M.; Solberg, E.D. Tillage and N source influence soil-emitted nitrous oxide in the Alberta Parkland region. Can. J. Soil Sci. 1999, 79, 15-24. [CrossRef]

10. Izaurralde, R.C.; Lemke, R.L.; Goddard, T.W.; McConkey, B.; Zhang, Z. Nitrous oxide emissions from agricultural toposequences in Alberta and Saskatchewan. Soil Sci. Soc. Am. J. 2004, 68, 1285-1294. [CrossRef]

11. Corre, M.D.; van Kessel, C.; Pennock, D.J. Landscape and seasonal patterns of nitrous oxide emissions in a semiarid region. Soil Sci. Soc. Am. J. 1996, 60, 1806-1815. [CrossRef]

12. Pennock, D.J.; Corre, M.D. Development and application of landform segmentation procedures. Soil Till. Res. 2001, 58, 151-162. [CrossRef]

13. Pennock, D.J.; Farrell, R.; Desjardin, R.L.; Pattey, E.; MacPherson, J.I. Upscaling chamber-based measurements of $\mathrm{N}_{2} \mathrm{O}$ emissions at snowmelt. Can. J. Soil Sci. 2005, 85, 113-125. [CrossRef]

14. Environment Canada. National Inventory Report 1990-2013: Greenhouse Gas Sources and Sinks in Canada; Environment Canada: Toronto, ON, Canada, 2015.

15. Chadwick, D.R.; Cardenas, L.; Misselbrook, T.H.; Smith, K.A.; Rees, R.M.; Watson, C.J.; McGeough, K.L.; Williams, J.R.; Cloy, J.M.; Thorman, R.A.; et al. Optimizing chamber methods for measuring nitrous oxide emissions from plot-based agricultural experiments. Eur. J. Soil Sci. 2014, 65, 295-307. [CrossRef]

16. Grant, R.F.; Pattey, E. Mathematical modelling of nitrous oxide emissions from an agricultural field during spring thaw. Glob. Biogeochem. Cycle 1999, 13, 679-694. [CrossRef]

17. Wagner-Riddle, C.; Furon, A.; McLaughlin, N.L.; Lee, I.; Barbeau, J.; Jayasundara, S.; Parkin, G.; von Bertoldi, P.; Warland, J. Intensive measurement of nitrous oxide emissions from a corn-soybean-wheat rotation under two contrasting management systems over 5 years. Glob. Chang. Biol. 2007, 13, 1722-1736. [CrossRef]

18. Pattey, E.; Blackburn, L.G.; Strachan, I.B.; Desjardins, R.L.; Dow, D. Spring-thaw and growing season $\mathrm{N}_{2} \mathrm{O}$ emissions from a field planted with edible peas and a cover crop. Can. J. Soil Sci. 2008, 88, 241-249. [CrossRef]

19. Glenn, A.J.; Tenuta, M.; Amiro, B.D.; Maas, S.E.; Wagner-Riddle, C. Nitrous oxide emissions from an annual crop rotation on poorly drained soil on the Canadian Prairies. Agric. For. Meteorol. 2012, 166, 41-49. [CrossRef]

20. Tenuta, M.; Gao, X.; Flaten, D.N.; Amiro, B.D. Lower nitrous oxide emissions from anhydrous ammonia application prior to soil freezing in late fall than spring pre-plant application. J. Environ. Qual. 2016, 45, 1133-1143. [CrossRef] [PubMed]

21. Intergovernmental Panel on Climate Change (IPCC). IPCC Guidelines for National Greenhouse Gas Inventories; Prepared by the National Greenhouse Gas Inventories Programme; IGES: Tsukuba, Japan, 2006.

22. Baron, V.S.; Doce, R.R.; Basarab, J.A.; Dick, C. Swath grazing triticale and corn compared to barley and a traditional winter feeding method in central Alberta. Can. J. Plant Sci. 2014, 94, 1125-1137. [CrossRef]

23. Alemu, A.W.; Doce, R.R.; Dick, A.C.; Basarab, J.A.; Kröbel, R.; Haugen-Kozyra, K.; Baron, V.S. Effect of winter feeding systems on farm greenhouse gas emissions. Agric. Syst. 2016, 148, 28-37. [CrossRef]

24. National Research Council (NRC). Nutrient Requirements of Beef Cattle; The National Academies Press: Washington, DC, USA, 2000.

25. Janzen, H.H.; Beauchemin, K.A.; Bruinsma, Y.; Campbell, C.; Desjardins, R.L.; Ellert, B.; Smith, E. The fate of nitrogen in agroecosystems: An illustration using Canadian estimates. Nutr. Cycl. Agroecosyst. 2003, 67, 85-102. [CrossRef]

26. Etheridge, R.D.; Pesti, G.M.; Foster, E.H. A comparison of nitrogen values obtained utilizing the Kjeldahl nitrogen and Dumas combustion methodologies (Leco CNS 2000) on samples typical of an animal nutrition analytical laboratory. Anim. Feed Sci. Technol. 1998, 73, 21-28. [CrossRef]

27. Flesch, T.K.; Baron, V.S.; Wilson, J.D.; Griffith, D.W.T.; Basarab, J.A.; Carlson, P.J. Agricultural gas emissions during the spring thaw: Applying a new measurement technique. Agric. For. Meteorol. 2016, 221, 111-121. [CrossRef]

28. Bai, M. Methane Emissions from Livestock Measured by Novel Spectroscopic Technique. Ph.D. Thesis, University of Wollongong, Wollongong, NSW, Australia, 2010.

29. Wilson, J.D.; Flesch, T.K. Generalized flux-gradient technique pairing line-average concentrations on vertically separated paths. Agric. For. Meteorol. 2016, 220, 170-176. [CrossRef]

30. Flesch, T.K.; Wilson, J.D.; Harper, L.A.; Crenna, B.P.; Sharpe, R.R. Deducing ground-air emissions from observed trace gas concentrations: A field trial. J. Appl. Meteorol. 2004, 43, 487-502. [CrossRef] 
31. Flesch, T.K.; McGinn, S.M.; Chen, D.; Wilson, J.D.; Desjardins, R.L. Data filtering for inverse dispersion calculations. Agric. For. Meteorol. 2015, 198-199, 1-6. [CrossRef]

32. Denmead, O.T.; Freney, J.R.; Simpson, J.R. Studies of nitrous oxide emission from a grass sward. Soil Sci. Soc. Am. J. 1979, 43, 726-728. [CrossRef]

33. Freibauer, A. Regionalised inventory of biogenic greenhouse gas emissions from European agriculture. Eur. J. Agron. 2003, 19, 135-160. [CrossRef]

34. Shcherbak, I.; Millar, N.; Robertson, G.P. Global meta analysis of the nonlinear response of soil nitrous oxide $\left(\mathrm{N}_{2} \mathrm{O}\right)$ emissions to fertilizer nitrogen. Proc. Natl. Acad. Sci. USA 2014, 111, 9199-9204. [CrossRef] [PubMed]

35. Christensen, S.; Christensen, B.T. Organic matter available for denitrification in different soil fractions: Effect of freeze/thaw cycles and straw disposal. J. Soil Sci. 1991, 42, 637-647. [CrossRef]

36. Thomas, S.M.; Beare, M.H.; Francis, G.S.; Barlow, H.E.; Hedderley, D.I. Effects of tillage, simulated cattle grazing and soil moisture on $\mathrm{N}_{2} \mathrm{O}$ emissions from a winter forage crop. Plant Soil 2008, 309, 131-145. [CrossRef]

37. Venterea, R.T. Theoretical comparison of advanced methods for calculating nitrous oxide fluxes using non-steady state chambers. Soil Sci. Soc. Am. J. 2013, 77, 709-720. [CrossRef]

38. Ryden, J.C.; Lund, L.J.; Focht, D.D. Direct infield measurement of nitrous oxide flux from soil. Soil Sci. Soc. Am. J. 1978, 42, 731-738. [CrossRef]

39. Blackmer, A.M.; Robbins, S.G.; Bremner, J.M. Diurnal variability in rate of emission of nitrous oxide from soils. Soil Sci. Soc. Am. J. 1982, 46, 937-942. [CrossRef]

40. Chapuis-Lardy, L.; Wrage, N..; Metay, A.; Chotte, J.; Bernoux, M. Soils, a sink for $\mathrm{N}_{2} \mathrm{O}$ ? A review. Glob. Chang. Biol. 2007, 13, 1-17. [CrossRef]

41. Wen, Y.; Chen, Z.; Dannenmann, M.; Carminati, A.; Willibald, G.; Kiese, R.; Wolf, B.; Veldkamp, E.; Butterbacn-Bahl, K.; Corre, M.D. Disentangling gross $\mathrm{N}_{2} \mathrm{O}$ production and consumption in soil. Sci. Rep. 2016, 6, 36517. [CrossRef] [PubMed]

(C) 2018 by the authors. Licensee MDPI, Basel, Switzerland. This article is an open access article distributed under the terms and conditions of the Creative Commons Attribution (CC BY) license (http:/ / creativecommons.org/licenses/by/4.0/). 